\title{
Using the Immunophenotype to Predict Response to Biologic Drugs in Rheumatoid Arthritis
}

\author{
Ben Mulhearn $1,2,3, * \mathbb{D}$, Anne Barton $2,3,4(\mathbb{D}$ and Sebastien Viatte $1,2,4 \mathbb{B}$ \\ 1 Manchester Collaborative Centre for Inflammation Research (MCCIR), Division of Infection, Immunity and \\ Respiratory Medicine, School of Biological Sciences, Faculty of Biology, Medicine and Health, Manchester \\ Academic Health Science Centre, University of Manchester, Manchester M13 9NT, UK; \\ sebastien.viatte@manchester.ac.uk \\ 2 Centre for Genetics and Genomics Versus Arthritis, Division of Musculoskeletal and Dermatological \\ Sciences, School of Biological Sciences, Faculty of Biology, Medicine and Health, Manchester Academic \\ Health Science Centre, University of Manchester, Manchester M13 9PT, UK; anne.barton@manchester.ac.uk \\ 3 Kellgren Centre for Rheumatology, NIHR Manchester BRC, Manchester University NHS Foundation Trust, \\ Manchester Academic Health Science Centre, Oxford Road, Manchester M13 9WL, UK \\ 4 Lydia Becker Institute of Immunology and Inflammation, Division of Musculoskeletal and Dermatological \\ Sciences, School of Biological Sciences, Faculty of Biology, Medicine and Health, The University of \\ Manchester, Manchester M13 9NT, UK \\ * Correspondence: ben.mulhearn@manchester.ac.uk; Tel.: +44-(0)-7803-166292
}

Received: 22 August 2019; Accepted: 19 September 2019; Published: 2 October 2019

\begin{abstract}
Tumour necrosis factor (TNF)- $\alpha$ is a key mediator of inflammation in rheumatoid arthritis, and its discovery led to the development of highly successful anti-TNF therapy. Subsequently, other biologic drugs targeting immune pathways, namely interleukin-6 blockade, B cell depletion, and T cell co-stimulation blockade, have been developed. Not all patients respond to a biologic drug, leading to a knowledge gap between biologic therapies available and the confident prediction of response. So far, genetic studies have failed to uncover clinically informative biomarkers to predict response. Given that the targets of biologics are immune pathways, immunological study has become all the more pertinent. Furthermore, advances in single-cell technology have enabled the characterization of many leucocyte subsets. Studying the blood immunophenotype may therefore, define biomarker profiles relevant to each individual patient's disease and treatment outcome. This review summarises our current understanding of how immune biomarkers might be able to predict treatment response to biologic drugs.
\end{abstract}

Keywords: immunology; rheumatoid arthritis; T cells; cytokines; biologic drugs; precision medicine; biomarkers

\section{Introduction}

Rheumatoid arthritis (RA) is a highly heterogeneous autoimmune disease characterised by inflammation of synovial joints with a prevalence of $0.5-1 \%$ and an incidence of $20-50$ per 100,000 annually [1]. Inflammation in the joints causes stiffness, pain, and swelling and may eventually lead to joint destruction due to cartilage and bone destruction. The heterogeneity of RA is becoming clearer as more evidence supports that the diagnosis encompasses a number of genetically related diseases that share joint inflammation as the presenting feature [2]. 
As a complex disease, subtle differences will also exist in the underlying immunological aetiopathologies. Current treatment strategies are designed to standardise treatment across patient groups which superficially appear similar but might have very different disease processes. Control of inflammation is critically important in the treatment of RA because there is a window of opportunity between the onset of inflammation and the onset of structural joint damage [3]. Structural joint damage leads to permanent disability which is detrimental to both the individual and societally [4]. It may even be possible to shut down the disease process entirely in very early rheumatoid arthritis (VERA), which is defined as less than three months of disease activity [5]. Personalised medicine aims to break the 'one size fits all' approach by tailoring therapy to subgroups of individuals with the aim of achieving a higher degree of treatment success from the outset.

The personalised approach will likely involve clinical, genetic, immunological, and hitherto unknown factors to inform treatment choice. Given that all treatments for RA without exception, target the immune system, whether that be by modulating serum cytokine signaling or by altering the cellular landscape, logic dictates that an understanding of the immune landscape before treatment begins should inform the prediction of treatment success or failure. This review aims to summarise our current understanding of how immunology might inform treatment choice in RA.

\section{Current Biologic Therapies Available}

There are four main classes of biologic drugs available in the United Kingdom, namely TNF inhibition, IL-6 inhibition, co-stimulation blockade, and B cell depletion. Newer targeted therapies such as JAK/STAT pathway inhibitors (e.g., tofacitinib and baricitinib) are not biologic drugs but act through tyrosine kinase inhibition and are known as 'small molecule inhibitors' (SMIs). In practice, as long as there are no contra-indications, the first-choice biologic/targeted therapy is usually the cheapest agent negotiated by the local Clinical Commissioning Group. In the UK, that is still currently anti-TNF biologics, but the situation may change according to cost, and biosimilars which are the biologic equivalent of generic medicines, are continually driving down the cost of biologic drugs. Rituximab as a first-line agent is reserved for those who have lupus cross-over syndrome, Felty's syndrome, or where anti-TNF is contra-indicated, but it currently remains a second-line agent for use after anti-TNF failure. Although it is recommended that all biologics are prescribed alongside methotrexate or another conventional disease-modifying anti-rheumatic drug (DMARD), adalimumab, etanercept, certolizumab pegol, and tocilizumab are licensed for use as monotherapy [6]. Figure 1 shows the sites of action of the main biologics used in RA.

\subsection{Anti-TNFs}

At present, available anti-TNF therapies include etanercept, adalimumab, infliximab, golimumab, and certolizumab pegol. Broadly, all are equally efficacious as each other, although for reasons not yet fully understood, some work better than others on an individual basis. All, except etanercept, are monoclonal antibodies, whilst etanercept consists of the TNF receptor fused to an Fc domain of IgG1 which binds free TNF [7]. The formation of anti-drug antibodies (ADAs) is one of the reasons for the secondary failure of anti-TNF monoclonal antibody drugs $[8,9]$. 


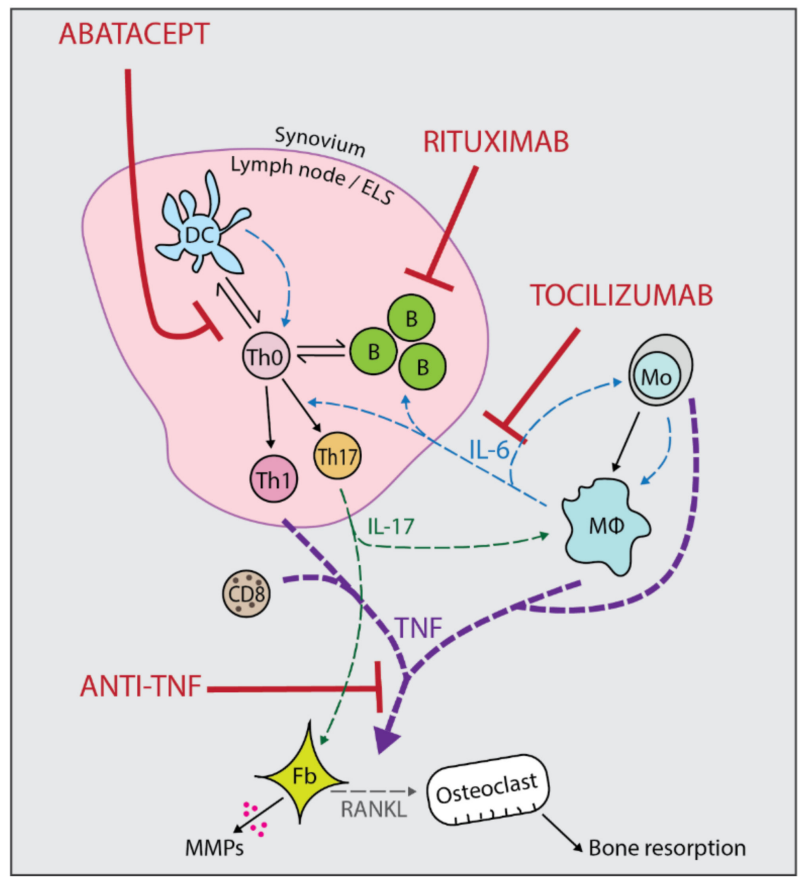

Figure 1. Sites of action of the main biologic drugs used in rheumatoid arthritis (RA). The cartoon represents the synovial membrane compartment with an associated ectopic lymphoid structure. Cytokine pathways are shown by dashed arrow lines. Abatacept works by blocking co-stimulation between DCs and T cells. Rituximab depletes B cells which may present antigen to T cells and produce autoantibodies. Tocilizumab blocks the actions of IL-6 which has many pro-inflammatory effects within the synovium. Anti-TNF blocks the actions of TNF which is able to activate fibroblasts and osteoclasts resulting in joint damage. B: B cell, CD8: Cytotoxic T cell, DC: Dendritic cell, ELS: Ectopic lymphoid structure, Fb: Fibroblast, MФ: Macrophage, Mo: Monocyte, T: T cell, Th0: Naïve T helper cell, Th1: T helper 1 cell, Th17: T helper 17 cell.

\subsection{Tocilizumab}

IL-6 was first found to be an important cytokine in RA as it drives the acute phase response causing systemic inflammation, including fever, high C-reactive peptide (CRP), and fatigue. Tocilizumab, a monoclonal antibody against the IL-6 receptor, blocks the actions of IL-6 and is effective in RA [10]. Tocilizumab monotherapy also reduces the radiographic progression of erosions in those with highly active disease [11]. It also improves the anaemia of chronic disease found in active RA compared to other biologics, DMARDs, and tofacitinib [12].

\subsection{Abatacept}

Cytotoxic T-lymphocyte-associated protein 4 (CTLA4) is a potent molecule found on activated T cells and Tregs, and binds the co-stimulatory molecules CD80 and CD86 found on antigen-presenting cells (APCs) with greater affinity than their ligand CD28, which is required for $\mathrm{T}$ cell receptor (TCR) activation on $\mathrm{T}$ cells (reviewed in [13]). The net effect is that naïve T cell activation is abrogated and CD80/CD86 expression on APCs is downregulated. Abatacept, a CTLA4-Fc fusion protein, was found to be efficacious for RA after inadequate response to an anti-TNF in the ATTAIN trial [14]. It is more expensive, although can be used first-line where anti-TNF agents might be contra-indicated. It appears to cause fewer serious adverse effects including infections than the other biologics as found in a Cochrane review [15]. 


\subsection{Rituximab}

Rituximab is an anti-CD20 antibody that depletes B cells and is effective in RA, further supporting a key role for B cells in RA pathogenesis [16]. The REFLEX trial found long-lasting response after one course of rituximab in those with inadequate response to one or more anti-TNFs [17]. Rituximab is effective in $70 \%$ of seropositive and $48 \%$ of seronegative patients [18]. The main safety considerations are the development of hypogammaglobulinaemia and neutropaenia which predispose to serious infections, and the reactivation of a number of fatal brain infections such as JC virus [19].

\section{Predicting Response to Biologic Drugs}

Predicting response to therapy is not currently possible using any meaningful demographic or biological parameters available in the clinic. It is however, an active area of research and highlighted below are some of the methods research groups have tried to address this problem. There are some promising results, although to date none of these have been translated into clinical practice. This is likely due to a lack of validation across different RA cohorts, low positive predictive values, and the unavailability in clinical practice of some of the biomarkers used, such as gene expression profiling or immunological assays.

\subsection{Clinical and Demographic Predictors of Response}

Baseline characteristics can predict better or poorer treatment outcomes. Response to biologics is associated with male gender and concomitant methotrexate, whereas non-response is associated with smoking and having a high baseline health assessment questionnaire (HAQ) score [20]. A regression model using clinical predictors of golimumab found that male gender, younger age, lower health assessment questionnaire (HAQ), erythrocyte sedimentation rate (ESR)/C-reactive peptide (CRP), tender joint count (TJC)/swollen joint count (SJC), and the absence of co-morbidities, could estimate remission rate using 3000 real-world patients [21]. This approach found that those with no comorbidities and the lowest inflammation were more likely to respond, therefore not being particularly informative in terms of choosing a particular biologic drug. Machine learning approaches have also been employed to generate treatment response algorithms. Miyoshi et al. (2016) reported that infliximab response could be predicted by using the nine variables of ESR, TJC, albumin, monocyte count, red blood cell number, prednisolone dose, methotrexate dose, $\mathrm{HbA1c}$, and previous biologic exposure with $92 \%$ accuracy [22]. However, these results were not confirmed in other anti-TNF cohorts, and infliximab is rarely used in the UK because it has to be given intravenously compared to the subcutaneous route of other anti-TNFs.

\subsection{Immunological Predictors of Response}

Interest has grown in identifying immunological biomarkers of treatment response. Methods include proteomic analysis of serum and flow cytometry to analyse panels of cell surface and intracellular markers of peripheral blood mononuclear cells (PBMCs). Synovial tissue and fluid are other sources of identifying biomarkers that may not be found in peripheral blood in the same quantities, given that the joint is the main site of pathology in RA. However, peripheral blood from patients is readily accessible in the clinic and PBMCs can be used in immunological studies and stimulation assays, whereas serum can be used for proteomics. The following section reviews immune biomarkers at baseline which have been reported to predict the response to biologics. Table 1 shows a summary of the main studies investigating immune biomarkers as predictors of treatment response. 
Table 1. Summary of the main studies investigating immune biomarkers as predictors of treatment response.

\begin{tabular}{|c|c|c|c|c|c|c|c|}
\hline Biomarker & Drug & Ethnicity & $\begin{array}{l}\text { Concurrent } \\
\text { DMARDs }\end{array}$ & Response Criteria & Predictor of Response & $N$ Cases & Reference \\
\hline \multirow[t]{18}{*}{$\begin{array}{l}\text { Seropositive } \\
\text { status }\end{array}$} & Infliximab & Caucasian & $100 \%$ & $\mathrm{DAS} 28 \geq 1.2$ & Low ACPA titre predictive of response (PPV 0.95) & 30 & [23] \\
\hline & & Caucasian & $73 \%$ & EULAR & Low RF/ACPA titre & 1195 & [24] \\
\hline & Infliximab & Asian & $100 \%$ & $\triangle \mathrm{CRP}$ & Low RF titre & 62 & [25] \\
\hline & & Caucasian & $100 \%$ & EULAR & ACPA not associated with response & 42 & {$[26]$} \\
\hline & & Caucasian & $100 \%$ & DAS28 & ACPA not associated with response & 31 & [27] \\
\hline & & Mixed & $\mathrm{n} / \mathrm{a}$ & $\begin{array}{c}\text { DAS28 } \\
\text { ACR20 } \\
\text { EULAR }\end{array}$ & $\begin{array}{l}\text { Meta-analysis found no association between seropositive status and } \\
\text { anti-TNF response }\end{array}$ & 5561 & [28] \\
\hline & Adalimumab & Caucasian & $100 \%$ & $\begin{array}{c}\text { EULAR } \\
\text { DAS28 } \\
\text { ACR20 }\end{array}$ & $\mathrm{ACPA}^{+}$ & 245 & [29] \\
\hline & Infliximab & Asian & $100 \%$ & DAS28 & High RF/ACPA titre & 307 & [30] \\
\hline & & Caucasian & $\mathrm{n} / \mathrm{a}$ & CDAI & No association & 1715 & [31] \\
\hline & Abatacept & Caucasian & $64.8 \%$ & EULAR & $\mathrm{ACPA}^{+}(\mathrm{OR} 1.9 ; 1.2-2.9)$ & 558 & [32] \\
\hline & & Caucasian & $100 \%$ & $\begin{array}{c}\text { EULAR } \\
\text { DAS28 } \\
\text { ACR20 }\end{array}$ & High ACPA titre & 252 & [29] \\
\hline & & Caucasian & $\mathrm{n} / \mathrm{a}$ & & Higher continuation of abatacept in seropositive cohorts & 1357 & [33] \\
\hline & & Caucasian & $\mathrm{n} / \mathrm{a}$ & CDAI & $\mathrm{ACPA}^{+}$ & 566 & [31] \\
\hline & & Caucasian & $75 \%$ & Retention rate & Double $\mathrm{RF}^{+} / \mathrm{ACPA}^{+}$ & 2350 & [34] \\
\hline & Rituximab & Mixed & $\mathrm{n} / \mathrm{a}$ & $\begin{array}{l}\text { ACR20 } \\
\text { EULAR }\end{array}$ & Meta-analysis found $\mathrm{RF}^{+}$associated with treatment response & 2103 & [35] \\
\hline & & Caucasian & $\mathrm{n} / \mathrm{a}$ & DAS28 & $\begin{array}{l}\text { Meta-analysis showing seropositive patients respond better to } \\
\text { rituximab than seronegative patients }\end{array}$ & 2177 & [36] \\
\hline & & Caucasian & $74.6 \%$ & $\begin{array}{l}\text { EULAR } \\
\text { DAS28 }\end{array}$ & High ACPA titre & 114 & [37] \\
\hline & Tocilizumab & Mixed & $\mathrm{n} / \mathrm{a}$ & $\begin{array}{l}\text { ACR20 } \\
\text { EULAR }\end{array}$ & Meta-analysis found $\mathrm{RF}^{+}$associated with treatment response & & [35] \\
\hline
\end{tabular}


Table 1. Cont.

\begin{tabular}{|c|c|c|c|c|c|c|c|}
\hline Biomarker & Drug & Ethnicity & $\begin{array}{l}\text { Concurrent } \\
\text { DMARDs }\end{array}$ & Response Criteria & Predictor of Response & $N$ Cases & Reference \\
\hline \multirow[t]{2}{*}{ IL-6 } & Etanercept & Asian & $\mathrm{n} / \mathrm{a}$ & $\mathrm{n} / \mathrm{a}$ & $\begin{array}{l}\text { Increased IL-6 (with low survivin) associated with response (OR 19.7, } \\
\text { CI 4.1-94.8) }\end{array}$ & 73 & [38] \\
\hline & Tocilizumab & Caucasian & $48.6 \%$ & EULAR & Increased IL-6 (with low IL-6R) associated with response & 63 & [39] \\
\hline IL-33 & Rituximab & Caucasian & $100 \%$ & EULAR & $\begin{array}{l}\text { High IL-33 (and } \mathrm{ACPA}^{+} \text {) associated with response (OR 29.61, CI } \\
1.3-674.8)\end{array}$ & 74 & [40] \\
\hline \multirow[t]{2}{*}{ CXCL13 } & Anti-TNFs & Caucasian & $100 \%$ & EULAR & $\begin{array}{l}\text { High CXCL13 (and high CXCL10) associated with response } \\
\text { (AUC 0.83) }\end{array}$ & 29 & [41] \\
\hline & Tocilizumab & Caucasian & $0 \%$ & ACR & High CXCL13 (with low sICAM1) (AUC 0.65) & 198 & [42] \\
\hline CCL19 & Rituximab & Caucasian & $100 \%$ & EULAR & High CCL19 associated with response (OR 1.43, CI 1.08-1.90) & 208 & [43] \\
\hline \multirow[t]{3}{*}{ B cells } & Anti-TNFs & Caucasian & $69 \%$ & EULAR & High CD27 ${ }^{+} B$ cells associated with response (RR 4.9, CI 1.3-18.6) & 21 & [44] \\
\hline & Abatacept & Caucasian & $51.2 \%$ & EULAR & High $\mathrm{CD} 27^{+}$and/or $\mathrm{CD} 38^{+} \mathrm{B}$ cells associated with response & 43 & [45] \\
\hline & Rituximab & Caucasian & $100 \%$ & EULAR & High CD27 ${ }^{-}$B cells are associated with response & 154 & [46] \\
\hline \multirow[t]{2}{*}{$\mathrm{CD}^{+} \mathrm{T}$ cells } & Etanercept & Caucasian & $\mathrm{n} / \mathrm{a}$ & EULAR & $\begin{array}{c}\text { High apoptotic epitope-specific CD8 }{ }^{+} \mathrm{T} \text { cells associated with } \\
\text { response (AUC 0.82) }\end{array}$ & 16 & [47] \\
\hline & Abatacept & Caucasian & $\mathrm{n} / \mathrm{a}$ & DAS28 & Low $\mathrm{CD} 28^{-} \mathrm{CD} 8^{+} \mathrm{T}$ cells is associated with response & 32 & [48] \\
\hline NK cells & Tocilizumab & Caucasian & $60 \%$ & DAS28 & Low $\mathrm{CD} 56^{\text {bright }} \mathrm{CD} 16^{-} \mathrm{NK}$ cells associated with response & 20 & [49] \\
\hline \multirow[t]{3}{*}{$\begin{array}{c}\text { Type I } \\
\text { interferon } \\
\text { signature }\end{array}$} & Anti-TNF & Hispanic & $71-100 \%$ & EULAR & $\begin{array}{l}\text { High type I IFN activity associated with response (OR 1.36, } \\
\text { CI 1.05-3.29) }\end{array}$ & 35 & [50] \\
\hline & Rituximab & Caucasian & $55 \%$ & EULAR & High type I IFN signature negatively associated with response & 20 & [51] \\
\hline & & Caucasian & $77 \%$ & DAS28 & $\begin{array}{l}\text { High type I IFN signature negatively associated with response } \\
\text { (AUC 0.87) }\end{array}$ & 26 & [52] \\
\hline
\end{tabular}

Table 1 outlines the main studies investigating immune biomarkers predicting treatment response in RA. Immune signatures are listed alongside the biologic drug studied, the ethnicity of the patient group, the percentage of the cohort taking concurrent disease-modifying anti-rheumatic drugs (DMARDs), the outcome measure used, the main findings, and the sample size. ACPA: Anti-citrullinated peptide antibody. ACR: American College of Rheumatology [53]. AUC: Area under the curve. CDAI: Clinical disease activity index. CI: Confidence interval. DAS28: Disease activity score in 28 joints [54]. EULAR: European League Against Rheumatism [55]. OR: Odds ratio. PPV: Positive predictive value. RF: Rheumatoid factor. 


\subsubsection{Anti-Citrullinated Peptide Antibodies and Rheumatoid Factor}

Many groups have investigated rheumatoid factor (RF) and anti-citrullinated peptide antibody (ACPA) positivity to predict response to therapy of all biologics. The reports for anti-TNF therapy are either conflicting [23-25,29,30] or did not find a correlation [26,27]. A meta-analysis of 5561 patients also did not find an association between ACPA/RF status and anti-TNF response [28].

Abatacept response appears to correlate with ACPA positivity with an odds ratio (OR) estimated to be between 1.4 and 1.9 in multiple studies [31-33]. The greatest response rates were seen in those with the highest titers of ACPA [29]. One real-world study found double ACPA/RF positivity resulted in higher abatacept retention rates, suggesting the efficacy of the drug in this multicenter cohort [34].

High titers of ACPA also predicted the best response to rituximab with an OR of 5.1 for good European League Against Rheumatism (EULAR) response [37]. A meta-analysis of 2177 patients confirmed the association between seropositivity and rituximab response, however, the effect was modest [36]. Finally, in another meta-analysis, RF status was associated with rituximab and tocilizumab response but not with abatacept [35].

\subsubsection{Serum Biomarkers}

Serum biomarkers are easy to measure and have been extensively researched because biologic drugs have cytokines as their target. Some promising reports are outlined below, although none have been validated in independent cohorts to date.

IL-6 at baseline is higher in responders to both etanercept and tocilizumab [38,39]. Furthermore, Shi et al. (2017) noted that high serum IL-6 and low serum survivin at baseline was associated with etanercept response with an OR of nearly 20 [38], and Diaz-Torne et al. (2017) found the patients showing the greatest response to tocilizumab had a combination of high serum IL-6 and low serum soluble IL-6 receptor [39].

IL-33 is a Th2 polarising cytokine, and when detected and added to ACPA status and serum IgG level, predicted $100 \%$ of rituximab responders with an OR of almost 30 in one study [40], although this work is yet to be validated in an independent cohort.

Chemokines direct the migration of leucocytes along a concentration gradient and are important to home cells to the sites of inflammation. Receiver operating characteristic (ROC) curve analysis found that high pre-treatment titers of the serum chemokines CXCL10 and CXCL13 predicted response to adalimumab and etanercept with an area under the curve (AUC) of 0.83 [41]. CCL19 was modestly associated with response to Rituximab with an OR of 1.48 [43]. In an innovative study integrating histopathology of synovial tissue with transcription profiling and serology, Dennis et al. (2014) found that elevated soluble ICAM1 (sICAM1) in the serum was associated with a synovial myeloid cell pathotype and good response to adalimumab, whereas CXCL13 predicted a synovial lymphoid pathotype and correlated with good tocilizumab response [42].

Proteomic approaches have also been tested for all the biologics, and although serum changes are usually seen in responders after treatment has begun, no baseline signature has yet been detected by most [56-58]. Obry et al. (2015) used quantitative mass spectrometry and identified 12 biomarkers which may have the capacity to predict response to etanercept/methotrexate [59]. This study found that S100A9 protein had the largest influence, although these findings might not be specific to anti-TNF treatment.

\subsubsection{Adaptive Immune Cells}

Given that the adaptive immune system is thought to be pivotal in the development and perpetuation of autoimmune diseases, investigating these populations in blood and at sites of inflammation could reveal important treatment response biomarkers. There is, however, a lack of consistency in studies on $\mathrm{T}$ and $\mathrm{B}$ cells in pre-treatment samples for predicting subsequent response. 
Baseline high levels of $\mathrm{CD} 27^{+}$memory B cells were associated with treatment response to anti-TNFs in one study with a relative risk (RR) of 4.9 [44]. High baseline memory B cells may also be associated with a good response to abatacept [45]. For rituximab, increased pre-treatment CD27- B cells (alongside RF positivity and a normal B cell count) were associated with response in one study [46].

Regarding $\mathrm{T}$ cells, $\mathrm{CD} 8^{+} \mathrm{T}$ cells specific for apoptosis-related antigens seen in chronic inflammation were significantly elevated in responders to anti-TNF therapy [47]. Baseline $\mathrm{CD} 8^{+} \mathrm{CD} 28^{-} \mathrm{T}$ cells were associated with a four-fold probability of response to abatacept at six months [48].

\subsubsection{Innate Immune Cells}

Monocytes can be subdivided into three groups according to their expression of CD14 and CD16 [60]. In RA, there is an increase in the number of CD16 $6^{+}$monocytes [61]. Chara et al., (2015) found that high pre-treatment levels of $\mathrm{CD} 14^{+} \mathrm{CD} 16^{-}$and $\mathrm{CD} 14^{+} \mathrm{CD} 16^{+}$monocytes correlated with reduced response to methotrexate [62]. The same group previously showed that these monocyte subsets remain high in non-responders to adalimumab/methotrexate after three months of therapy with $86 \%$ positive predictive value (PPV) [63]. Monocyte subsets might therefore, prove to be an attractive pre-treatment biomarker, and further research should aim to uncover if these cell numbers change in response to other treatment regimens.

Another group studied NK cells and found that low $\mathrm{CD} 56^{\text {bri }} \mathrm{CD} 16^{-} \mathrm{NK}$ cells at baseline were associated with response to tocilizumab, but not to anti-TNF therapy [49]. CD56 ${ }^{\mathrm{dim}} \mathrm{CD} 16^{+} \mathrm{NK}$ cells showed no association, thereby leading the authors to conclude that there may be a pathogenetic link between patients who respond to anti-IL-6 therapy and their $\mathrm{CD} 56^{\text {bri }} \mathrm{CD} 16^{-} \mathrm{NK}$ cells. Interestingly, such NK cells are capable of secreting many cytokines including GM-CSF, IFN $\gamma$ and TNF [64].

\subsubsection{Interferon Gene Signatures}

The interferon gene signature refers to type I interferons and includes genes up and down-regulated by interferons- $\alpha$ and $-\beta$. It is often measured indirectly by interferon-response gene quantification where a score is then assigned. In RA patients, $50 \%$ with established disease have a high type I interferon signature, and some hypothesise that these patients may have different underlying mechanisms of disease [65]. A high baseline interferon signature was significantly associated with anti-TNF response [50]. In contrast, detecting a high type I interferon signature may predict reduced response to rituximab [51]. This was supported by a prospective analysis of 14 RA patients commenced on rituximab, with further validation in 26 RA patients with an area under the curve (AUC) of 0.87 [52]. Furthermore, prednisolone treatment drives down type I interferon signatures and prediction of rituximab response was therefore, highest in the prednisolone-negative group with an AUC of 0.97 [66]. These data suggest that those patients with a high baseline type I interferon signature respond well to anti-TNF and less well to rituximab, which may indicate differences in pathogenesis in the two groups. However, there is significant methodological variability over different studies in detecting the type I interferon signature which means its use as a clinical biomarker is limited until a standardised approach is developed [67].

\subsection{Multiplexed Prediction Models}

It is likely that a combination of demographic, clinical, laboratory markers, genetics, epigenetics, as well as proteomics, functional immunology, and gene expression profiling will be needed to build up a personalised profile to predict treatment response for each individual patient [68,69]. Dennis et al. used a combination of global gene expression, synovial histology, and cellular analyses to identify pre-treatment serum biomarkers which predict response to anti-TNF therapy [42]. Based on synovial gene expression, they describe the four synovial pathotypes: lymphoid, myeloid, low inflammatory, and fibroid. They observed differences in the number of $B$ cells in each phenotype with high numbers in the lymphoid and myeloid groups and an absence of B cells in the low inflammatory and fibroid groups. Two serum biomarkers were identified which reflected two different synovial phenotypes: sICAM1 
titers reflected the myeloid phenotype, and the chemokine CXCL13 reflected the lymphoid phenotype. Finally, the group found that sICAM ${ }^{\text {high }} \mathrm{CXCL} 13^{\text {low }}$, i.e., the myeloid pathotype, had higher responses to anti-TNF inhibition with adalimumab, whereas sICAM ${ }^{\text {low }}$ CXCL13 $3^{\text {high }}$ lymphoid pathotype patients had the largest response rates to tocilizumab.

The COMBINE study used multi-omics data (DNA, RNA, proteomics, flow cytometry) to find predictors of anti-TNF response, and found that a combination could explain $51 \%$ of the variation in DAS28 with an AUC of 0.815 [70], although such approaches are not currently feasible on a large scale. The findings require independent validation as the model is likely to be over-fitted, having been derived from a single dataset.

As synovial biopsy becomes more readily performed and accepted by patients, transcriptomics of specific cell types is being performed to build up a transcriptional profile of synovial macrophages [71]. It is likely that such cutting-edge technologies will be integrated with clinical and immune biomarkers to further develop prediction models, and this is the subject of several on-going studies including the MATURA program in the UK [72] and the Accelerated Medicines Partnership RA/SLE Network in the US [73].

\section{Conclusions}

New treatments for rheumatoid arthritis and other autoimmune diseases are now targeted towards specific components of the immune system. Whereas, monoclonal antibodies are highly specific for their immune targets, SMIs such as JAK-STAT inhibitors target intracellular signaling downstream of cytokine receptors [74]. Immune cells have a central role in autoimmune pathology, and given that they are also targets of these treatments, investigations of immunophenotyping and treatment response are all the more important. The exploration of serum proteins, for example, cytokines, has not so far been fruitful in revealing treatment response biomarkers [75]. Other disciplines have utilised functional immunology to identify diagnostic or theragnostic biomarkers. For example, the IFN $\gamma$-release assay (IGRA) uses tuberculosis antigens to stimulate $\mathrm{CD}^{+} \mathrm{T}$ cells and measures the level of IFN $\gamma$ release to determine previous tuberculosis exposure [76].

Currently, immunophenotyping is not yet useful in clinical practice to predict response to therapy in any discipline, although intense research is ongoing in the fields of oncology [77], hematology [78], rheumatology [79], and transplant medicine [80]. Developing reproducible methods of immune cell phenotyping is therefore crucial to both understanding mechanisms of disease and to discovering cellular immune biomarkers to predict treatment response. We feel that the future of treatment prediction lies in the inclusion of a number of cellular and serum biomarkers, which may or may not include functional immunological assays, combined with recognised clinical predictors of response, into a multivariate prediction model for each immune-mediated disease. High-throughput methods of measuring each of these variables will only make such models more accurate in their prediction of response.

Author Contributions: A.B. and S.V. conceived the review. B.M. wrote the first draft of the manuscript. All authors contributed to the manuscript discussion, writing and reviewing.

Funding: No specific funding was received from any bodies in the public, commercial or not-for-profit sectors to carry out the work described in this article.

Acknowledgments: A.B. is in receipt of an NIHR Senior Investigator award. The authors would like to acknowledge the assistance given by the support team at the University of Manchester Centre for Genetics and Genomics Versus Arthritis and The Manchester Collaborative Centre for Inflammation Research (MCCIR) headed by Professor Tracy Hussell. This work was supported by the NIHR Manchester Biomedical Research Centre.

Conflicts of Interest: The authors declare no conflict of interest. 


\section{References}

1. Alamanos, Y.; Drosos, A.A. Epidemiology of adult rheumatoid arthritis. Autoimmun. Rev. 2005, 4, 130-136. [CrossRef] [PubMed]

2. Pratt, A.G.; Isaacs, J.D. Seronegative rheumatoid arthritis: Pathogenetic and therapeutic aspects. Best Pract. Res. Clin. Rheumatol. 2014, 28, 651-659. [CrossRef] [PubMed]

3. Anderson, J.J.; Wells, G.; Verhoeven, A.C.; Felson, D.T. Factors predicting response to treatment in rheumatoid arthritis: The importance of disease duration. Arthritis Rheum. 2000, 43, 22-29. [CrossRef]

4. Breedveld, F. The value of early intervention in RA-A window of opportunity. Clin. Rheumatol. 2011, 30, 33-39. [CrossRef] [PubMed]

5. Raza, K.; Buckley, C.E.; Salmon, M.; Buckley, C.D. Treating very early rheumatoid arthritis. Best Pract. Res. Clin. Rheumatol. 2006, 20,849-863. [CrossRef]

6. National Institue for Health and Clinical Excellence. The Management of Rheumatoid Arthritis in Adults. (Clinical Guideline 79); National Institue for Health and Clinical Excellence: London, UK, 2009.

7. Weinblatt, M.E.; Kremer, J.M.; Bankhurst, A.D.; Bulpitt, K.J.; Fleischmann, R.M.; Fox, R.I.; Jackson, C.G.; Lange, M.; Burge, D.J. A Trial of Etanercept, a Recombinant Tumor Necrosis Factor Receptor: Fc Fusion Protein, in Patients with Rheumatoid Arthritis Receiving Methotrexate. N. Engl. J. Med. 1999, 340, $253-259$. [CrossRef]

8. Wolbink, G.J.; Vis, M.; Lems, W.; Voskuyl, A.E.; de Groot, E.; Nurmohamed, M.T.; Stapel, S.; Tak, P.P.; Aarden, L.; Dijkmans, B. Development of antiinfliximab antibodies and relationship to clinical response in patients with rheumatoid arthritis. Arthritis Rheum. 2006, 54, 711-715. [CrossRef] [PubMed]

9. Bartelds, G.M.; Wijbrandts, C.A.; Nurmohamed, M.T.; Stapel, S.; Lems, W.F.; Aarden, L.; Dijkmans, B.A.C.; Tak, P.P.; Wolbink, G.J. Clinical response to adalimumab: Relationship to anti-adalimumab antibodies and serum adalimumab concentrations in rheumatoid arthritis. Ann. Rheum. Dis. 2007, 66, 921-926. [CrossRef]

10. Choy, E.H.S.; Isenberg, D.A.; Garrood, T.; Farrow, S.; Ioannou, Y.; Bird, H.; Cheung, N.; Williams, B.; Hazleman, B.; Price, R.; et al. Therapeutic benefit of blocking interleukin- 6 activity with an anti-interleukin-6 receptor monoclonal antibody in rheumatoid arthritis: A randomized, double-blind, placebo-controlled, dose-escalation trial. Arthritis Rheum. 2002, 46, 3143-3150. [CrossRef]

11. Nishimoto, N.; Hashimoto, J.; Miyasaka, N.; Yamamoto, K.; Kawai, S.; Takeuchi, T.; Murata, N.; van der Heijde, D.; Kishimoto, T. Study of active controlled monotherapy used for rheumatoid arthritis, an IL-6 inhibitor (SAMURAI): Evidence of clinical and radiographic benefit from an $x$ ray reader-blinded randomised controlled trial of tocilizumab. Ann. Rheum. Dis. 2007, 66, 1162-1167. [CrossRef]

12. Paul, S.K.; Montvida, O.; Best, J.H.; Gale, S.; Pethoe-Schramm, A.; Sarsour, K. Effectiveness of biologic and non-biologic antirheumatic drugs on anaemia markers in 153,788 patients with rheumatoid arthritis: New evidence from real-world data. Semin. Arthritis Rheum. 2018, 47, 478-484. [CrossRef] [PubMed]

13. Walker, L.S.K.; Sansom, D.M. The emerging role of CTLA4 as a cell-extrinsic regulator of T cell responses. Nat. Rev. Immunol. 2011, 11, 852-863. [CrossRef] [PubMed]

14. Genovese, M.C.; Schiff, M.; Luggen, M.; Becker, J.-C.; Aranda, R.; Teng, J.; Li, T.; Schmidely, N.; Le Bars, M.; Dougados, M. Efficacy and safety of the selective co-stimulation modulator abatacept following 2 years of treatment in patients with rheumatoid arthritis and an inadequate response to anti-tumour necrosis factor therapy. Ann. Rheum. Dis. 2007, 67, 547-554. [CrossRef] [PubMed]

15. Singh, J.A.; Wells, G.A.; Christensen, R.; Tanjong Ghogomu, E.; Maxwell, L.J.; MacDonald, J.K.; Filippini, G.; Skoetz, N.; Francis, D.K.; Lopes, L.C.; et al. Adverse effects of biologics: A network meta-analysis and Cochrane overview. Cochrane Database Syst. Rev. 2011. [CrossRef] [PubMed]

16. Edwards, J.C.W.; Szczepanski, L.; Szechinski, J.; Filipowicz-Sosnowska, A.; Emery, P.; Close, D.R.; Stevens, R.M.; Shaw, T. Efficacy of B-cell-targeted therapy with rituximab in patients with rheumatoid arthritis. N. Engl. J. Med. 2004, 350, 2572-2581. [CrossRef] [PubMed]

17. Cohen, S.B.; Emery, P.; Greenwald, M.W.; Dougados, M.; Furie, R.A.; Genovese, M.C.; Keystone, E.C.; Loveless, J.E.; Burmester, G.-R.; Cravets, M.W.; et al. Rituximab for rheumatoid arthritis refractory to anti-tumor necrosis factor therapy: Results of a multicenter, randomized, double-blind, placebo-controlled, phase III trial evaluating primary efficacy and safety at twenty-four weeks. Arthritis Rheum. 2006, 54, 2793-2806. [CrossRef] [PubMed] 
18. Sellam, J.; Hendel-Chavez, H.; Rouanet, S.; Abbed, K.; Combe, B.; Le Loët, X.; Tebib, J.; Sibilia, J.; Taoufik, Y.; Dougados, M.; et al. B cell activation biomarkers as predictive factors for the response to rituximab in rheumatoid arthritis: A six-month, national, multicenter, open-label study. Arthritis Rheum. 2011, 63, 933-938. [CrossRef]

19. van Vollenhoven, R.F.; Fleischmann, R.M.; Furst, D.E.; Lacey, S.; Lehane, P.B. Longterm Safety of Rituximab: Final Report of the Rheumatoid Arthritis Global Clinical Trial Program over 11 Years. J. Rheumatol. 2015, 42, 1761-1766. [CrossRef]

20. Hyrich, K.L.; Watson, K.D.; Silman, A.J.; Symmons, D.P.M. Predictors of response to anti-TNF-alpha therapy among patients with rheumatoid arthritis: Results from the British Society for Rheumatology Biologics Register. Rheumatology (Oxf.) 2006, 45, 1558-1565. [CrossRef] [PubMed]

21. Vastesaeger, N.; Kutzbach, A.G.; Amital, H.; Pavelka, K.; Lazaro, M.A.; Moots, R.J.; Wollenhaupt, J.; Zerbini, C.A.F.; Louw, I.; Combe, B.; et al. Prediction of remission and low disease activity in disease-modifying anti-rheumatic drug-refractory patients with rheumatoid arthritis treated with golimumab. Rheumatology 2016, 55, 1466-1476. [CrossRef]

22. Miyoshi, F.; Honne, K.; Minota, S.; Okada, M.; Ogawa, N.; Mimura, T. A novel method predicting clinical response using only background clinical data in RA patients before treatment with infliximab. Mod. Rheumatol. 2016, 26, 813-816. [CrossRef] [PubMed]

23. Braun-Moscovici, Y.; Markovits, D.; Zinder, O.; Schapira, D.; Rozin, A.; Ehrenburg, M.; Dain, L.; Hoffer, E.; Nahir, A.M.; Balbir-Gurman, A. Anti-cyclic citrullinated protein antibodies as a predictor of response to anti-tumor necrosis factor-alpha therapy in patients with rheumatoid arthritis. J. Rheumatol. 2006, 33, 497-500. [PubMed]

24. Potter, C.; Hyrich, K.L.; Tracey, A.; Lunt, M.; Plant, D.; Symmons, D.P.M.; Thomson, W.; Worthington, J.; Emery, P.; Morgan, A.W.; et al. Association of rheumatoid factor and anti-cyclic citrullinated peptide positivity, but not carriage of shared epitope or PTPN22 susceptibility variants, with anti-tumour necrosis factor response in rheumatoid arthritis. Ann. Rheum. Dis. 2009, 68, 69-74. [CrossRef] [PubMed]

25. Nozaki, Y.; Nagare, Y.; Hino, S.; Yano, T.; Kishimoto, K.; Shimazu, H.; Ikoma, S.; Kinoshita, K.; Funauchi, M. Therapeutic strategy and significance of serum rheumatoid factor in patients with rheumatoid arthritis during infliximab treatment. Nihon Rinsho Meneki Gakkai Kaishi 2010, 33, 135-141. [CrossRef] [PubMed]

26. Dejaco, C.; Duftner, C.; Klotz, W.; Schirmer, M.; Herold, M. Third generation anti-cyclic citrullinated peptide antibodies do not predict anti-TNF- $\alpha$ treatment response in rheumatoid arthritis. Rheumatol. Int. 2010, 30, 451-454. [CrossRef] [PubMed]

27. Vasilopoulos, Y.; Bagiatis, V.; Stamatopoulou, D.; Zisopoulos, D.; Alexiou, I.; Sarafidou, T.; Settas, L.; Sakkas, L.; Mamuris, Z. Association of anti-CCP positivity and carriage of TNFRII susceptibility variant with anti-TNF-?? response in rheumatoid arthritis. Clin. Exp. Rheumatol. 2011, 29, 701-704.

28. Lv, Q.; Yin, Y.; Li, X.; Shan, G.; Wu, X.; Liang, D.; Li, Y.; Zhang, X. The Status of Rheumatoid Factor and Anti-Cyclic Citrullinated Peptide Antibody Are Not Associated with the Effect of Anti-TNF $\alpha$ Agent Treatment in Patients with Rheumatoid Arthritis: A Meta-Analysis. PLoS ONE 2014, 9, e89442. [CrossRef] [PubMed]

29. Sokolove, J.; Schiff, M.; Fleischmann, R.; Weinblatt, M.E.; Connolly, S.E.; Johnsen, A.; Zhu, J.; Maldonado, M.A.; Patel, S.; Robinson, W.H. Impact of baseline anti-cyclic citrullinated peptide-2 antibody concentration on efficacy outcomes following treatment with subcutaneous abatacept or adalimumab: 2-year results from the AMPLE trial. Ann. Rheum. Dis. 2015, 75, 709-714. [CrossRef]

30. Takeuchi, T.; Miyasaka, N.; Inui, T.; Yano, T.; Yoshinari, T.; Abe, T.; Koike, T. High titers of both rheumatoid factor and anti-CCP antibodies at baseline in patients with rheumatoid arthritis are associated with increased circulating baseline TNF level, low drug levels, and reduced clinical responses: A post hoc analysis of the RISING study. Arthritis Res. Ther. 2017, 19, 194.

31. Harrold, L.R.; Litman, H.J.; Connolly, S.E.; Kelly, S.; Hua, W.; Alemao, E.; Rosenblatt, L.; Rebello, S.; Kremer, J.M. Effect of Anticitrullinated Protein Antibody Status on Response to Abatacept or Antitumor Necrosis Factor- $\alpha$ Therapy in Patients with Rheumatoid Arthritis: A US National Observational Study. J. Rheumatol. 2017, 45, 170007. [CrossRef] 
32. Gottenberg, J.E.; Ravaud, P.; Cantagrel, A.; Combe, B.; Flipo, R.M.; Schaeverbeke, T.; Houvenagel, E.; Gaudin, P.; Loeuille, D.; Rist, S.; et al. Positivity for anti-cyclic citrullinated peptide is associated with a better response to abatacept: Data from the "Orencia and Rheumatoid Arthritis" registry. Ann. Rheum. Dis. 2012, 71, 1815-1819. [CrossRef] [PubMed]

33. Gottenberg, J.E.; Courvoisier, D.S.; Hernandez, M.V.; Iannone, F.; Lie, E.; Canhão, H.; Pavelka, K.; Hetland, M.L.; Turesson, C.; Mariette, X.; et al. Brief Report: Association of Rheumatoid Factor and Anti-Citrullinated Protein Antibody Positivity With Better Effectiveness of Abatacept: Results From the Pan-European Registry Analysis. Arthritis Rheumatol. (Hoboken, N.J.) 2016, 68, 1346-1352. [CrossRef] [PubMed]

34. Alten, R.; Mariette, X.; Lorenz, H.-M.; Galeazzi, M.; Cantagrel, A.; Nüßlein, H.G.; Chartier, M.; Elbez, Y.; Rauch, C.; Le Bars, M. Real-world predictors of 12-month intravenous abatacept retention in patients with rheumatoid arthritis in the ACTION observational study. RMD Open 2017, 3, e000538. [CrossRef] [PubMed]

35. Maneiro, R.J.; Salgado, E.; Carmona, L.; Gomez-Reino, J.J. Rheumatoid factor as predictor of response to abatacept, rituximab and tocilizumab in rheumatoid arthritis: Systematic review and meta-analysis. Semin. Arthritis Rheum. 2013, 43, 9-17. [CrossRef]

36. Isaacs, J.D.; Cohen, S.B.; Emery, P.; Tak, P.P.; Wang, J.; Lei, G.; Williams, S.; Lal, P.; Read, S.J. Effect of baseline rheumatoid factor and anticitrullinated peptide antibody serotype on rituximab clinical response: A meta-analysis. Ann. Rheum. Dis. 2013, 72, 329-336. [CrossRef]

37. Gardette, A.; Ottaviani, S.; Tubach, F.; Roy, C.; Nicaise-Roland, P.; Palazzo, E.; Gill, G.; Meyer, O.; Dieudé, P. High anti-CCP antibody titres predict good response to rituximab in patients with active rheumatoid arthritis. Joint. Bone Spine 2014, 81, 416-420. [CrossRef]

38. Shi, R.; Chen, M.; Litifu, B. Serum interleukin-6 and survivin levels predict clinical response to etanercept treatment in patients with established rheumatoid arthritis. Mod. Rheumatol. 2018, 28, 126-132. [CrossRef]

39. Diaz-Torne, C.; Ortiz, M.D.A.; Moya, P.; Hernandez, M.V.; Reina, D.; Castellvi, I.; De Agustin, J.J.; de la Fuente, D.; Corominas, H.; Sanmarti, R.; et al. The combination of IL-6 and its soluble receptor is associated with the response of rheumatoid arthritis patients to tocilizumab. Semin. Arthritis Rheum. 2017, 47, 757-764. [CrossRef]

40. Sellam, J.; Rivière, E.; Courties, A.; Rouzaire, P.-O.; Tolusso, B.; Vital, E.M.; Emery, P.; Ferraccioli, G.; Soubrier, M.; Ly, B.; et al. Serum IL-33, a new marker predicting response to rituximab in rheumatoid arthritis. Arthritis Res. Ther. 2016, 18, 294. [CrossRef]

41. Han, B.K.; Kuzin, I.; Gaughan, J.P.; Olsen, N.J.; Bottaro, A. Baseline CXCL10 and CXCL13 levels are predictive biomarkers for tumor necrosis factor inhibitor therapy in patients with moderate to severe rheumatoid arthritis: A pilot, prospective study. Arthritis Res. Ther. 2016, 18, 93. [CrossRef]

42. Dennis, G.; Holweg, C.T.J.; Kummerfeld, S.K.; Choy, D.F.; Setiadi, A.F.; Hackney, J.A.; Haverty, P.M.; Gilbert, H.; Lin, W.Y.; Diehl, L.; et al. Synovial phenotypes in rheumatoid arthritis correlate with response to biologic therapeutics. Arthritis Res. Ther. 2014, 16, R90. [CrossRef] [PubMed]

43. Sellam, J.; Rouanet, S.; Hendel-Chavez, H.; Miceli-Richard, C.; Combe, B.; Sibilia, J.; Le Loët, X.; Tebib, J.; Jourdan, R.; Dougados, M.; et al. CCL19, a B Cell Chemokine, Is Related to the Decrease of Blood Memory B Cells and Predicts the Clinical Response to Rituximab in Patients With Rheumatoid Arthritis. Arthritis Rheum. 2013, 65, 2253-2261. [CrossRef] [PubMed]

44. Daien, C.I.; Gailhac, S.; Mura, T.; Combe, B.; Hahne, M.; Morel, J. High levels of memory B cells are associated with response to a first tumor necrosis factor inhibitor in patients with rheumatoid arthritis in a longitudinal prospective study. Arthritis Res. Ther. 2014, 16, R95. [CrossRef] [PubMed]

45. Gazeau, P.; Alegria, G.C.; Devauchelle-Pensec, V.; Jamin, C.; Lemerle, J.; Bendaoud, B.; Brooks, W.H.; Saraux, A.; Cornec, D.; Renaudineau, Y. Memory B Cells and Response to Abatacept in Rheumatoid Arthritis. Clin. Rev. Allergy Immunol. 2017, 53, 166-176. [CrossRef]

46. Tony, H.-P.; Roll, P.; Mei, H.E.; Blümner, E.; Straka, A.; Gnuegge, L.; Dörner, T.; FIRST/ReFIRST study teams. Combination of $\mathrm{B}$ cell biomarkers as independent predictors of response in patients with rheumatoid arthritis treated with rituximab. Clin. Exp. Rheumatol. 2015, 33, 887-894. [PubMed]

47. Citro, A.; Scrivo, R.; Martini, H.; Martire, C.; De Marzio, P.; Vestri, A.R.; Sidney, J.; Sette, A.; Barnaba, V.; Valesini, G. CD8+ T Cells Specific to Apoptosis-Associated Antigens Predict the Response to Tumor Necrosis Factor Inhibitor Therapy in Rheumatoid Arthritis. PLoS ONE 2015, 10, e0128607. [CrossRef] 
48. Scarsi, M.; Ziglioli, T.; Airo, P. Baseline numbers of circulating CD28-negative T cells may predict clinical response to abatacept in patients with rheumatoid arthritis. J. Rheumatol. 2011, 38, 2105-2111. [CrossRef]

49. Daien, C.I.; Gailhac, S.; Audo, R.; Mura, T.; Hahne, M.; Combe, B.; Morel, J.; Daïen, C.I.; Gailhac, S.; Audo, R.; et al. High levels of natural killer cells are associated with response to tocilizumab in patients with severe rheumatoid arthritis. Rheumatology (Oxf.) 2014, 54, 1-8. [CrossRef]

50. Mavragani, C.P.; La, D.T.; Stohl, W.; Crow, M.K. Association of the response to tumor necrosis factor antagonists with plasma type I interferon activity and interferon-beta/alpha ratios in rheumatoid arthritis patients: A post hoc analysis of a predominantly Hispanic cohort. Arthritis Rheum. 2010, 62, 392-401. [CrossRef]

51. Thurlings, R.M.; Boumans, M.; Tekstra, J.; van Roon, J.A.; Vos, K.; van Westing, D.M.; van Baarsen, L.G.; Bos, C.; Kirou, K.A.; Gerlag, D.M.; et al. Relationship between the type I interferon signature and the response to rituximab in rheumatoid arthritis patients. Arthritis Rheum. 2010, 62, 3607-3614. [CrossRef]

52. Raterman, H.G.; Vosslamber, S.; de Ridder, S.; Nurmohamed, M.T.; Lems, W.F.; Boers, M.; van de Wiel, M.; Dijkmans, B.A.C.; Verweij, C.L.; Voskuyl, A.E. The interferon type I signature towards prediction of non-response to rituximab in rheumatoid arthritis patients. Arthritis Res. Ther. 2012, 14, R95. [CrossRef] [PubMed]

53. Felson, D.T.; Anderson, J.J.; Boers, M.; Bombardier, C.; Furst, D.; Goldsmith, C.; Katz, L.M.; Lightfoot, R.; Paulus, H.; Strand, V. American College of Rheumatology. Preliminary definition of improvement in rheumatoid arthritis. Arthritis Rheum. 1995, 38, 727-735. [CrossRef] [PubMed]

54. Prevoo, M.L.; van 't Hof, M.A.; Kuper, H.H.; van Leeuwen, M.A.; van de Putte, L.B.; van Riel, P.L. Modified disease activity scores that include twenty-eight-joint counts. Development and validation in a prospective longitudinal study of patients with rheumatoid arthritis. Arthritis Rheum. 1995, 38, 44-48. [CrossRef] [PubMed]

55. van Gestel, A.M.; Prevoo, M.L.; van't Hof, M.A.; van Rijswijk, M.H.; van de Putte, L.B.; van Riel, P.L. Development and validation of the European League Against Rheumatism response criteria for rheumatoid arthritis. Comparison with the preliminary American College of Rheumatology and the World Health Organization/International League Against Rheumatism Cri. Arthritis Rheum. 1996, 39, 34-40. [CrossRef] [PubMed]

56. Fabre, S.; Guisset, C.; Tatem, L.; Dossat, N.; Dupuy, A.M.; Cohen, J.D.; Cristol, J.P.; Daures, J.P.; Jorgensen, C. Protein biochip array technology to monitor rituximab in rheumatoid arthritis. Clin. Exp. Immunol. 2009, 155, 395-402. [CrossRef] [PubMed]

57. Ortea, I.; Roschitzki, B.; López-Rodríguez, R.; Tomero, E.G.; Ovalles, J.G.; López-Longo, J.; de la Torre, I.; González-Alvaro, I.; Gómez-Reino, J.J.; González, A. Independent Candidate Serum Protein Biomarkers of Response to Adalimumab and to Infliximab in Rheumatoid Arthritis: An Exploratory Study. PLoS ONE 2016, 11, e0153140. [CrossRef]

58. Cuppen, B.; Fritsch-Stork, R.; Eekhout, I.; de Jager, W.; Marijnissen, A.; Bijlsma, J.; Custers, M.; van Laar, J.; Lafeber, F.; Welsing, P.; et al. Proteomics to predict the response to tumour necrosis factor- $\alpha$ inhibitors in rheumatoid arthritis using a supervised cluster-analysis based protein score. Scand. J. Rheumatol. 2017, 47, 12-21. [CrossRef] [PubMed]

59. Obry, A.; Hardouin, J.; Lequerré, T.; Jarnier, F.; Boyer, O.; Fardellone, P.; Philippe, P.; Marcelli, C.; Loët, X.L.; Vittecoq, O.; et al. Identification of 7 Proteins in Sera of RA Patients with Potential to Predict ETA/MTX Treatment Response. Theranostics 2015, 5, 1214-1224. [CrossRef]

60. Ziegler-Heitbrock, L.; Ancuta, P.; Crowe, S.; Dalod, M.; Grau, V.; Hart, D.N.; Leenen, P.J.M.; Liu, Y.-J.Y.-J.; MacPherson, G.; Randolph, G.J.; et al. Nomenclature of monocytes and dendritic cells in blood. Blood 2010, 116, e74-e80. [CrossRef]

61. Baeten, D.; Boots, A.M.H.; Steenbakkers, P.G.A.; Elewaut, D.; Bos, E.; Verheijden, G.F.M.; Verbruggen, G.; Miltenburg, A.M.M.; Rijnders, A.W.M.; Veys, E.M.; et al. Human cartilage gp-39, CD16+ monocytes in peripheral blood and synovium: Correlation with joint destruction in rheumatoid arthritis. Arthritis Rheum. 2000, 43, 1233-1243. [CrossRef] 
62. Chara, L.; Sánchez-Atrio, A.; Pérez, A.; Cuende, E.; Albarrán, F.; Turrión, A.; Chevarria, J.; Del Barco, A.; Sánchez, M.A.; Monserrat, J.; et al. The number of circulating monocytes as biomarkers of the clinical response to methotrexate in untreated patients with rheumatoid arthritis. J. Transl. Med. 2015, 13, 2. [CrossRef] [PubMed]

63. Chara, L.; Sánchez-Atrio, A.; Pérez, A.; Cuende, E.; Albarrán, F.; Turrión, A.; Chevarria, J.; Sánchez, M.A.; Monserrat, J.; de la Hera, A.; et al. Monocyte populations as markers of response to adalimumab plus MTX in rheumatoid arthritis. Arthritis Res. Ther. 2012, 14, R175. [CrossRef] [PubMed]

64. Cooper, M.A.; Fehniger, T.A.; Turner, S.C.; Chen, K.S.; Ghaheri, B.A.; Ghayur, T.; Carson, W.E.; Caligiuri, M.A. Human natural killer cells: A unique innate immunoregulatory role for the CD56(bright) subset. Blood 2001, 97, 3146-3151. [CrossRef] [PubMed]

65. van der Pouw Kraan, T.C.T.M.; Wijbrandts, C.A.; van Baarsen, L.G.M.; Voskuyl, A.E.; Rustenburg, F.; Baggen, J.M.; Ibrahim, S.M.; Fero, M.; Dijkmans, B.A.C.; Tak, P.P.; et al. Rheumatoid arthritis subtypes identified by genomic profiling of peripheral blood cells: Assignment of a type I interferon signature in a subpopulation of patients. Ann. Rheum. Dis. 2007, 66, 1008-1014. [CrossRef] [PubMed]

66. de Jong, T.D.; Vosslamber, S.; Blits, M.; Wolbink, G.; Nurmohamed, M.T.; van der Laken, C.J.; Jansen, G.; Voskuyl, A.E.; Verweij, C.L. Effect of prednisone on type I interferon signature in rheumatoid arthritis: Consequences for response prediction to rituximab. Arthritis Res. Ther. 2015, 17, 78. [CrossRef] [PubMed]

67. Rodríguez-Carrio, J.; Alperi-López, M.; López, P.; Ballina-García, F.J.; Suárez, A. Heterogeneity of the Type I Interferon Signature in Rheumatoid Arthritis: A Potential Limitation for Its Use As a Clinical Biomarker. Front. Immunol. 2018, 8, 2007. [CrossRef] [PubMed]

68. Hueber, W.; Tomooka, B.H.; Batliwalla, F.; Li, W.; Monach, P.A.; Tibshirani, R.J.; Van Vollenhoven, R.F.; Lampa, J.; Saito, K.; Tanaka, Y.; et al. Blood autoantibody and cytokine profiles predict response to anti-tumor necrosis factor therapy in rheumatoid arthritis. Arthritis Res. Ther. 2009, 11, R76. [CrossRef]

69. Ally, M.M.T.M.; Hodkinson, B.; Meyer, P.W.A.; Musenge, E.; Tintinger, G.R.; Tikly, M.; Anderson, R. Circulating anti-citrullinated peptide antibodies, cytokines and genotype as biomarkers of response to disease-modifying antirheumatic drug therapy in early rheumatoid arthritis. BMC Musculoskelet. Disord. 2015, 16, 130. [CrossRef]

70. Folkersen, L.; Brynedal, B.; Diaz-Gallo, L.M.; Ramsköld, D.; Shchetynsky, K.; Westerlind, H.; Sundström, Y.; Schepis, D.; Hensvold, A.; Vivar, N.; et al. Integration of known DNA, RNA and protein biomarkers provides prediction of anti-TNF response in rheumatoid arthritis: Results from the COMBINE study. Mol. Med. 2016, 22, 322-328. [CrossRef]

71. Mandelin, A.M.; Homan, P.J.; Shaffer, A.M.; Cuda, C.M.; Dominguez, S.T.; Bacalao, E.; Carns, M.; Hinchcliff, M.; Lee, J.; Aren, K.; et al. Transcriptional Profiling of Synovial Macrophages using Minimally Invasive Ultrasound-Guided Synovial Biopsies in Rheumatoid Arthritis. Arthritis Rheumatol. (Hoboken, N.J.) 2018, 70, 841-854. [CrossRef]

72. Barton, A.; Pitzalis, C. Stratified medicine in rheumatoid arthritis-the MATURA programme. Rheumatology (Oxf.) 2017, 56, 1247-1250. [CrossRef] [PubMed]

73. Donlin, L.T.; Rao, D.A.; Wei, K.; Slowikowski, K.; McGeachy, M.J.; Turner, J.D.; Meednu, N.; Mizoguchi, F.; Gutierrez-Arcelus, M.; Lieb, D.J.; et al. Methods for high-dimensonal analysis of cells dissociated from cyropreserved synovial tissue. Arthritis Res. Ther. 2018, 20, 139. [CrossRef] [PubMed]

74. Gadina, M.; Gazaniga, N.; Vian, L.; Furumoto, Y. Small molecules to the rescue: Inhibition of cytokine signaling in immune-mediated diseases. J. Autoimmun. 2017, 85, 20-31. [CrossRef] [PubMed]

75. Burska, A.; Boissinot, M.; Ponchel, F. Cytokines as biomarkers in rheumatoid arthritis. Mediat. Inflamm. 2014, 2014, 545493. [CrossRef]

76. HPA Tuberculosis Programme Board. Health Protection Agency Position Statement on the Use of Interferon Gamma Release Assay (IGRA) Tests for Tuberculosis (TB) Introduction and Background; Health Protection Agency: London, UK, 2012.

77. Singh, U.; Cui, Y.; Dimaano, N.; Mehta, S.; Pruitt, S.; Yearley, J.; Laterza, O.; Juco, J.; Dogdas, B. Analytical validation of quantitative immunohistochemical assays of tumor infiltrating lymphocyte biomarkers. Biotech. Histochem. 2018, 93, 411-423. [CrossRef] [PubMed]

78. Brück, O.; Blom, S.; Dufva, O.; Turkki, R.; Chheda, H.; Ribeiro, A.; Kovanen, P.; Aittokallio, T.; Koskenvesa, P.; Kallioniemi, O.; et al. Immune cell contexture in the bone marrow tumor microenvironment impacts therapy response in CML. Leukemia 2018, 32, 1643. [CrossRef] 
79. Ermann, J.; Rao, D.A.; Teslovich, N.C.; Brenner, M.B.; Raychaudhuri, S. Immune cell profiling to guide therapeutic decisions in rheumatic diseases. Nat. Rev. Rheumatol. 2015, 11, 541-551. [CrossRef]

80. Yabu, J.M.; Siebert, J.C.; Maecker, H.T. Immune Profiles to Predict Response to Desensitization Therapy in Highly HLA-Sensitized Kidney Transplant Candidates. PLoS ONE 2016, 11, e0153355. [CrossRef]

(C) 2019 by the authors. Licensee MDPI, Basel, Switzerland. This article is an open access article distributed under the terms and conditions of the Creative Commons Attribution (CC BY) license (http://creativecommons.org/licenses/by/4.0/). 